\title{
High Throughput Screening for Inhibitors of Alpha-Galactosidase
}

\author{
Omid Motabar ${ }^{1,2}, \mathrm{Ke} \mathrm{Liu}^{1}$, Noel Southall ${ }^{1}$, Juan J. Marugan ${ }^{1}$, Ehud Goldin² ${ }^{2}$ Ellen Sidransky ${ }^{2}$ and \\ Wei Zheng*,1
}

\author{
${ }^{I}$ NIH Chemical Genomics Center and ${ }^{2}$ Medical Genetics Branch, National Human Genome Research Institute, National \\ Institutes of Health, Bethesda, MD 20892-3370, USA
}

\begin{abstract}
Fabry disease is a rare X-linked lysosomal storage disorder caused by a deficiency in $\alpha$-galactosidase A (GLA), which catalyzes the hydrolysis of terminal $\alpha$-galactosyl groups from glycosphingolipids, such as globotriaosylceramide (Gb3). Many of the mutations in the GLA gene are missense alterations that cause misfolding, decreased stability, and/or mistrafficking of this protein. Small molecule compounds that correct the misfolding and mistrafficking, or activate the mutant enzyme, may be useful in the treatment of Fabry disease. We have screened a library of approximately 230,000 compounds using preparations of human recombinant protein and purified coffee bean enzyme in an effort to find activators and inhibitors of this enzyme. Lansoprazole was identified as a small molecule inhibitor of GLA derived from coffee beans $\left(\mathrm{IC}_{50}=6.4 \mu \mathrm{M}\right)$, but no inhibitors or activators were identified for the human enzyme. The screening results indicate that human GLA is a difficult target for small molecule inhibition or activation.
\end{abstract}

Keywords: Alpha-galactosidase, inhibitor, Fabry disease, drug target, high throughput screening.

\section{INTRODUCTION}

Alpha-galactosidase A (GLA) is a lysosomal enzyme that catalyzes the hydrolysis of terminal $\alpha$-galactosyl moieties from glycolipids and glycoproteins. Mutations in the GLA gene can result in the synthesis of misfolded proteins that are retained in the endoplasmic reticulum and degraded prematurely. In Fabry disease, a deficiency in GLA results in the accumulation of globotriaosylceramide (Gb3), a glycosphingolipid, in many cells and organs of the body, including endothelial cells and the smooth muscle cells of blood vessels [1]. Patients with Fabry disease present clinically with chronic neuronopathic pain, gastrointestinal disturbances, angiokeratomata, progressive renal impairment, cardiomyopathy, premature myocardial infarctions, and stroke, and both life expectancy and quality of life are severely compromised. Enzyme replacement therapy (ERT) has been available for the treatment of Fabry disease since 2001, and is effective in treating the symptoms, but has drawbacks as well $[2,3]$. In addition to ERT, there is great interest in correcting enzyme misfolding with small molecules, a strategy referred to as chemical chaperone therapy (CCT). Chemical chaperones are small molecules that bind to mutant proteins and assist in their correct folding, maturation, and trafficking to the functional site, such as the lysosomes. The effects of chemical chaperones have been explored in various lysosomal storage disorders, including Gaucher disease [4-7], Pompe disease $[8,9]$, Tay-Sachs/Sandhoff disease [10], GM1-gangliosidosis [11], as well as Fabry disease. A GLA inhibitor, 1-deoxygalactonojirimycin (DGJ, marketed as Amigal $^{\mathrm{TM}}$ by Amicus Therapeutics, Inc.), is currently being studied in a phase 3 clinical trial as a chaperone therapeutic agent for Fabry disease [12]. In this chemical chaperone

*Address correspondence to this author at the 9800 Medical Center Drive, MSC 3370, Bethesda, MD 20892-3370, Tel: 301-217-5720; Fax: 301-2175728; E-mail: wzheng@mail.nih.gov therapy, small molecule inhibitors bind to misfolded proteins and correct their folding, maturation and/or trafficking resulting in increased delivery of GLA to lysosomes. Once in the lysosomes the inhibitors bound to GLA are displaced by the abundant substrates. However, DGJ is an iminosugar analog which may not have the desirable drug selectivity, and may potentially cause adverse effects. Thus, new improved GLA inhibitors with chaperone activity, as well as enzyme activators, are needed for drug development for Fabry disease.

Several enzyme assays are available for the high throughput screening (HTS) of small molecule compound libraries against GLA. Chromogenic assays are available that use $p$-nitrophenol- $\alpha$-D-galactopyranoside $[13,14]$ or naphthyl- $\alpha$-D-galactopyranoside [15] as substrates. However, absorbance-based assays are usually less sensitive than fluorescence-based assays, and cannot be easily miniaturized into a high-density 1536-well plate format for HTS. The profluorogenic molecule, 4-methylumbelliferyl- $\alpha$-D-galactopyranoside (4MU- $\alpha$-Gala), is a substrate for GLA, where the product of the enzyme reaction emits blue fluorescence at a peak of $440 \mathrm{~nm}$ upon excitement at $365 \mathrm{~nm}[16,17]$. Resorufinyl $\alpha$-D-galactopyranoside (res- $\alpha$-Gala) is a red profluorogenic GLA substrate which excites at $573 \mathrm{~nm}$ and emits at $610 \mathrm{~nm}$ upon galactose cleavage $[18,19]$. We report here the identification of a novel small molecule GLA inhibitor from a compound library screen using these profluorogenic substrates. GLA from green coffee beans, which is readily available, was used in the initial assay development and screen validation. Using that protein, we identified a novel small molecule inhibitor of GLA, lansoprazole. However, in a subsequent screen of 230,000 compounds using the human recombinant GLA, we did not find any hits, indicating the difficulty of targeting the human enzyme. 


\section{MATERIALS AND METHODS}

\section{Enzymes, Substrates, and Other Chemicals}

$\alpha$-Galactosidase A from green coffee beans (G8507, 10 units/mg protein) and $\alpha$-glucosidase from rice (G9259, 40-80 units/mg protein) were purchased from Sigma-Aldrich (St. Louis, MO). Glucocerebrosidase was obtained from residual solution after clinical infusions of imiglucerase $\left(\right.$ Cerezyme ${ }^{\circledR}$, Genzyme Co., $\mathrm{Mr}=60,430)$, with a specific activity of 42.2 units/mg and 14 units $/ \mathrm{ml}$. Recombinant human $\alpha$ Galactosidase A was also obtained from residual solution after clinical infusions (agalsidase beta, marketed as Fabrazyme $^{\circledR}$ by Genzyme Co.). Glycerol was added to these enzyme solutions to $30 \%$, and small aliquots were stored at $80^{\circ} \mathrm{C}$. Enzyme activity was found to be stable in these stock solutions after storage at $-80^{\circ} \mathrm{C}$ for 2 years.

4-methylumbelliferyl- $\alpha$-D-galactopyranoside (4MU- $\alpha-$ Gala), a blue pro-fluorogenic substrate, and 1deoxygalactonojirimycin (DGJ), a known inhibitor of $\alpha$ galactosidase, were purchased from Sigma-Aldrich, as were citric acid, potassium phosphate trihydrate, tween-20, glycine, and sodium hydroxide. Taurocholic acid sodium salt was obtained from CalbioChem (a subsidiary of EMD Bioscience, San Diego, CA). Four compound libraries, the LOPAC (Library of Pharmacologically Active Compounds) collection, the Prestwick collection, the Spectrum collection, and the Tocris collection were purchased from SigmaAldrich, Prestwick Chemicals (Illkirch, France), MicroSource Discovery Systems (Gaylordsville, CT) and Tocris (Ellisville, MO), respectively.

\section{Buffers}

The assay buffer for the $\alpha$-galactosidase and glucocerebrosidase enzyme assays consisted of $50 \mathrm{mM}$ citric acid, 176 $\mathrm{mM} \mathrm{K} \mathrm{PO}_{4}$, and $0.01 \%$ Tween-20 at $\mathrm{pH}$ 5.9. The assay buffer for $\alpha$-glucosidase was similar, except that it was titrated with $\mathrm{K}_{2} \mathrm{PO}_{4}$ to $\mathrm{pH} 5.0$. The buffers were stored at $4{ }^{\circ} \mathrm{C}$ for use up to 6 months. The stop solution consisted of $0.5 \mathrm{M}$ sodium hydroxide and $0.5 \mathrm{M}$ glycine at $\mathrm{pH}$ 11.6.

\section{Instruments for Liquid Handling and Plate Detection}

An $\mathrm{FRD}^{\mathrm{TM}}$ automated microvolume dispensing station (Aurora Discovery, San Diego, CA) was used to dispense reagents into 1536-well plates at volumes from 1-3 $\mu$ l. Initially, the compounds were serially diluted in DMSO in 384well plates using a $\mathrm{CyBi}^{\circledR}$-Well dispensing station with a 384-well head (Cybio Inc., Woburn, MA), and then reformatted into 1536-well plates at $7 \mu \mathrm{l} /$ well. Nanoliter volumes of these compounds were transferred to 1536-well assay plates using an automated pin-tool station (Kalypsys, Inc., San Diego, CA). A ViewLux ${ }^{\mathrm{TM}}$ CCD-based imaging plate reader (PerkinElmer, Boston, MA) was used for fluorescence detection at a speed of 30 seconds per plate. A Safire2 ${ }^{\text {TM }}$ monochromator scanning fluorescence plate reader (Tecan Group Ltd., Männedorf, Switzerland) was used for determining the fluorescence excitation and emission spectra.

\section{Enzyme Kinetics Assay}

The kinetics assay was carried out in a 384-well plate format using $1 \mathrm{nM}$ enzyme with varying concentrations of substrate. Initially, $10 \mu \mathrm{l} /$ well of the varying concentrations of substrate were added to the plate. The reaction was initi- ated by addition of $20 \mu \mathrm{l} /$ well of enzyme solution. The 4MU$\alpha$-Gala stock solution was serially diluted $1: 1.5$ to give eight concentrations. The final concentrations of substrate used in the assay were $500,333,222,148,98.8,65.8,43.9$, and 29.3 $\mu \mathrm{M} .30 \mu \mathrm{l} /$ well of stop solution was added after $2,4,6,8,10$, and 12 minute incubation times at RT. A standard curve of the free fluorophore, 4-methylumbelliferone (4MU), in the same volume of assay buffer and stop solution was generated for calculating the enzyme product. The plate was read in the ViewLux plate reader at an emission wavelength of $440 \mathrm{~nm}$ and an excitation wavelength of $365 \mathrm{~nm}$.

In order to determine the type of inhibition and the inhibition constant of lansoprazole, five enzyme kinetics plots were generated in the presence of $80,40,20,10$, and $0 \mu \mathrm{M}$ of the inhibitor. The final concentrations of substrate were $500,333,222,148,98.8,65.8,43.9,29.3$, and $19.5 \mu \mathrm{M}$. The plate was read in the ViewLux at $2,4,6,8$, and 10 minute time intervals. As in the above kinetic assay, a standard curve of the free fluorophore, 4MU, was generated. The plate was read at $440 \mathrm{~nm}$ emission upon excitation at 365 $\mathrm{nm}$.

\section{qHTS of Compound Collections}

Quantitative high-throughput screening (qHTS) is a method for simultaneously screening large compound libraries at multiple concentrations. The Library of Pharmacologically Active Compounds (LOPAC) with 1,280 compounds from Sigma-Aldrich is commonly used to validate the screening assay. Once validated, NCGC's collection of 230,000 compounds was screened for GLA activity. The compounds in these libraries were serially diluted in DMSO at a ratio of 1:5 for up to seven concentrations in 384-well plates. Four sets of the inter-plate dilution plates were reformatted into one set of 1536-well plates, with compound concentrations ranging from $0.29 \mu \mathrm{M}$ to $10 \mathrm{mM}$. The pintool station was used to transfer $23 \mathrm{nl}$ of compounds in DMSO solution to the assay plates with the enzyme solutions. The final compound concentrations in a $3 \mu \mathrm{l}$ assay volume ranged from $1.9 \mathrm{nM}$ to $66.7 \mu \mathrm{M}$.

\section{Other Enzyme Assays to Determine Compound Selectiv- ity}

The enzyme assays of two other hydrolases, rice $\alpha$ glucosidase (GAA) and human recombinant glucocerebrosidase (GC) were used for determining the selectivity of the active compounds identified from HTS. Both enzyme assays employed the similar fluorogenic substrates, 4methylumbelliferyl- $\alpha$-D-glucopyranoside (4MU- $\alpha$-glc) for GAA and 4-methylumbelliferyl $\beta$-D-glucopyranoside (4MU$\beta$-Glc) for GC, which were purchased from Sigma-Aldrich (St. Louis, MO). The assays were performed in 1536-well black assay plates with $2 \mu \mathrm{l} /$ well enzyme and $23 \mathrm{nl} /$ well of compound in DMSO solution followed by $1 \mu \mathrm{l} /$ well substrate solution. After a 30-minute incubation at the room temperature $\left(2{ }^{\circ} \mathrm{C}\right), 3 \mu \mathrm{l} /$ well of stop solution was added and the assay plates were counted in a Viewlux plate reader for fluorescence intensity at an excitation of $365 \mathrm{~nm}$ and emission of $440 \mathrm{~nm}$. As described previously [7], the final enzyme concentration was $8 \mathrm{nM}$ and substrate concentration was 160 $\mu \mathrm{M}$ for the GAA assay, while the final enzyme and substrate concentrations in the GC assay were $1.9 \mathrm{nM}$ and $800 \mu \mathrm{M}$, respectively. 


\section{Data Analysis}

The primary screen data was analyzed and concentration responses were fit using a customized software developed internally $[20,21]$. The results from the assay optimization experiments, enzyme kinetics, confirmation experiments, and selectivity assays were analyzed with Prism ${ }^{\circledR}$ (Graphpad, San Diego, CA).

\section{RESULTS AND DISCUSSION}

\section{Screening Assay Optimization}

The GLA enzyme assay was initially developed using commercially available purified enzyme from green coffee beans. The classical fluorogenic substrate used, $4 \mathrm{MU}-\alpha-$ Gala, forms two products, galactose and fluorescent $4 \mathrm{MU}$, upon cleavage by GLA. Since this enzyme is naturally found in the lysosomes, $\mathrm{pH}$ optimization was first performed. A $\mathrm{pH}$ titration revealed an optimal $\mathrm{pH}$ of 5.9 (Fig. 1a) for this enzyme assay, and this buffer $\mathrm{pH}$ was used for subsequent experiments. An addition of stop solution after the enzyme reaction raised the final $\mathrm{pH}$ in assay plates to 10 for optimal fluorescence detection, because the 4MU fluorophore has a $\mathrm{pK}_{\mathrm{a}}$ of 7.8 and its fluorescence intensity is not favorably detected below this $\mathrm{pK}_{\mathrm{a}}$ value.

While sodium taurocholate is routinely used in the GLA assay buffer [22], its optimal concentration has not been well-established. It is a bile salt that is required for the activity of certain lysosomal enzymes [23]. A titration of sodium taurocholate was performed in this enzyme assay to establish its optimal concentration. Unexpectedly, we found that sodium taurocholate decreased the GLA activity at all the concentrations tested (ranging from 0.15 to $40 \mathrm{mM}$ ) (Fig. 1b), while enzyme activity was quite high without this bile salt.

(a)

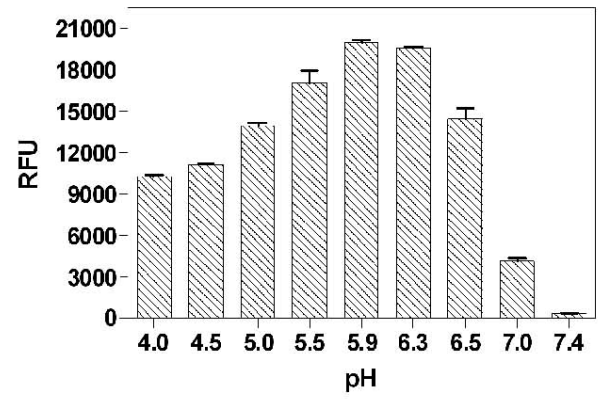

(c)

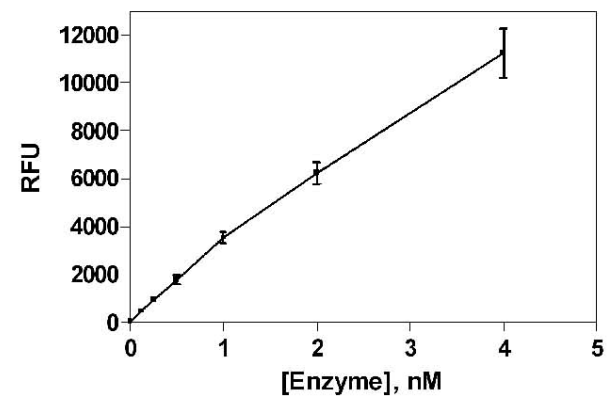

This result contrasts with the sodium taurocholate dependence of glucocerebrosidase, another lysosomal enzyme, which shows almost no enzyme activity in the absence of this bile salt [7]. Thus, sodium taurocholate was eliminated from the GLA assay buffer.

The enzyme concentration-response was also measured at a fixed substrate concentration in order to establish the optimal enzyme concentration for compound screening. It showed a nearly linear response from $0.125 \mathrm{nM}$ to $4 \mathrm{nM}$ GLA (Fig. 1c). Based on this result, $1 \mathrm{nM}$ enzyme was selected for the assay because the fluorescence intensity ( $4000 \mathrm{RFU})$ was adequate, while the substrate consumption was under $10 \%$ at this enzyme concentration. An incubation of 20 minutes at RT was selected because the enzyme activity was linear during a 40 minute incubation time (data not shown).

DMSO tolerance of this enzyme assay was also evaluated, as it is the solvent used for dissolving library compounds. It was found that the enzyme activity slightly decreased with increasing DMSO concentrations (Fig. 1d). The enzyme activity was not significantly decreased at the $0.76 \%$ DMSO concentration used for the compound screens.

\section{Enzyme Kinetics}

The enzyme kinetics experiments were performed using $1 \mathrm{nM}$ enzyme with substrate concentrations ranging from 30 to $500 \mathrm{uM}$. It was found that the $\mathrm{K}_{\mathrm{m}}$ was $144 \mu \mathrm{M}$ and the $\mathrm{V}_{\max } 5.74 \mathrm{pmol} / \mathrm{min}$ at the optimal $\mathrm{pH}$ of 5.9 (Fig. 2a). This is similar to the value of $239 \mu \mathrm{M}$, determined with the same substrate, but at $\mathrm{pH} 6.5$ [24]. In addition, a kinetic analysis was done at the previously used $\mathrm{pH}$ of 4.5 [25], and the $\mathrm{K}_{\mathrm{m}}$ and $\mathrm{V}_{\max }$ were found to be $102 \mu \mathrm{M}$ and $2.76 \mathrm{pmol} / \mathrm{min}$, re-

(b)

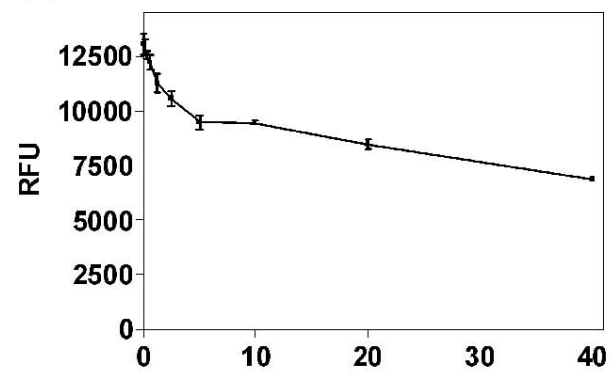

[Sodium Taurocholate], mM

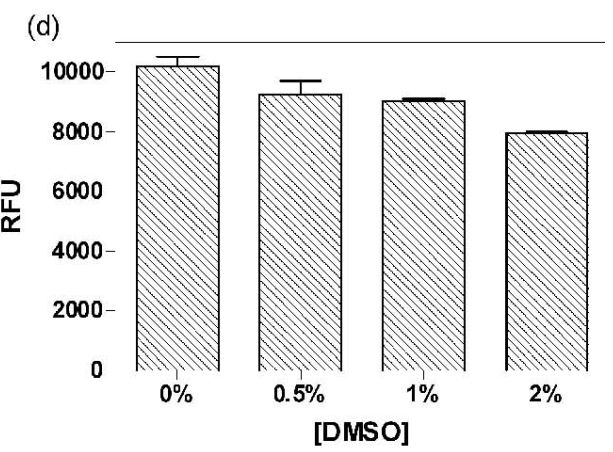

Fig. (1). Optimization of the GLA assay. (a) GLA activity at different pH values. The optimal pH was 5.9. (b) Effect of sodium taurocholate. GLA activity decreased with increasing concentrations of sodium taurocholate. (c) Enzyme concentration-response. The enzyme activity increased nearly linearly from 0.125 to $4 \mathrm{nM} \mathrm{GLA}$. (d) DMSO tolerance. Fluorescence slightly decreased as DMSO concentration increased. 

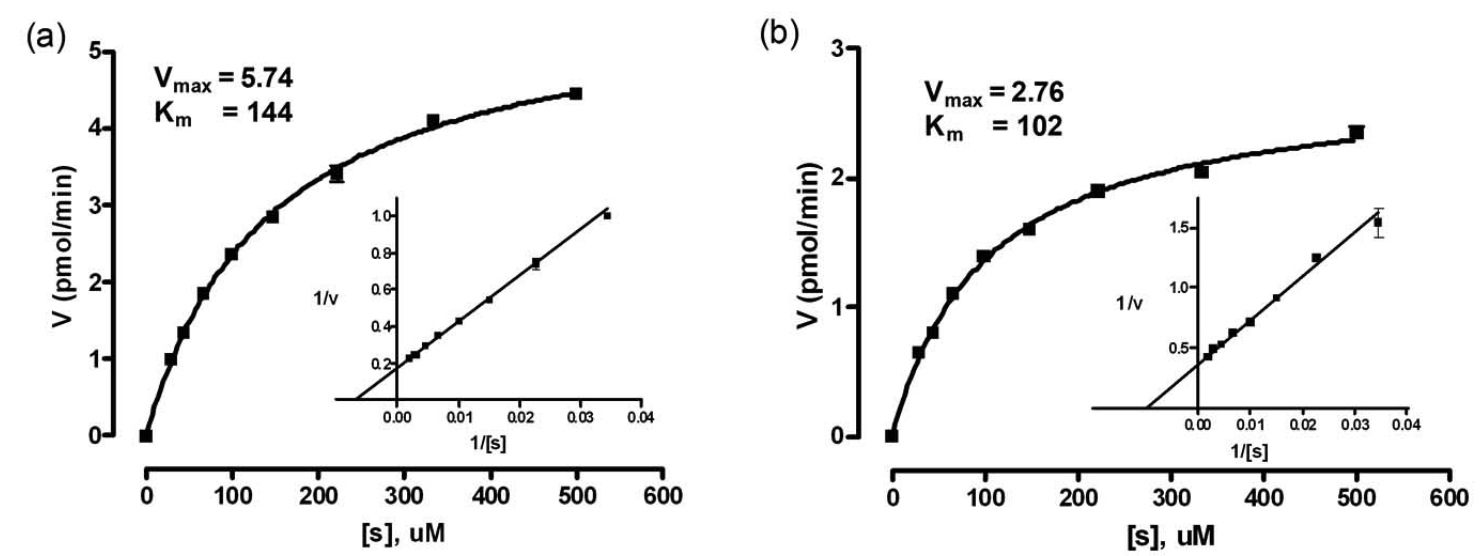

Fig. (2). Enzyme kinetics. (a) At the optimal pH of 5.9, the enzyme had a $\mathrm{K}_{\mathrm{m}}$ of $144 \mu \mathrm{M}$ and a $\mathrm{V}_{\max }$ of $5.74 \mathrm{pmol} / \mathrm{min}$. (b) At an acidic lysosomal $\mathrm{pH}$ of 4.5 , the enzyme had a $\mathrm{K}_{\mathrm{m}}$ of $102 \mu \mathrm{M}$ and a $\mathrm{V}_{\max }$ of $2.76 \mathrm{pmol} / \mathrm{min}$.

spectively (Fig. 2b). The $\mathrm{K}_{\mathrm{m}}$ values were similar for the two assays, while the rate of substrate cleavage was about two fold greater at $\mathrm{pH} 5.9$ than at $\mathrm{pH} 4.5 .40 \mu \mathrm{M}$ of $4 \mathrm{MU}-\alpha-$ Gala was chosen as the substrate concentration for this assay, as it was less than the $\mathrm{K}_{\mathrm{m}}$ value (important for compound screening sensitivity) and gave sufficient fluorescence.

Thus, for compound screening, $1 \mathrm{nM}$ GLA and $40 \mu \mathrm{M}$ $4 \mathrm{MU}-\alpha$-Gala were chosen as the enzyme and substrate concentrations, respectively. The assay was performed at $\mathrm{pH} 5.9$ with 20 minutes incubation at RT.

\section{IC $_{50}$ Determination of a Known GLA Inhibitor}

For further assay validation, the activity of a known inhibitor, 1-deoxygalactonojirimycin (DGJ), was evaluated using this enzyme assay. The $\mathrm{IC}_{50}$ value of this known inhibitor was $5.6 \mathrm{nM}$ in this enzyme assay (Fig. 3), which is similar to the reported $\mathrm{IC}_{50}$ value of $3 \mathrm{nM}$ [26]. This compound was used as an internal control in the subsequent compound screening experiments.

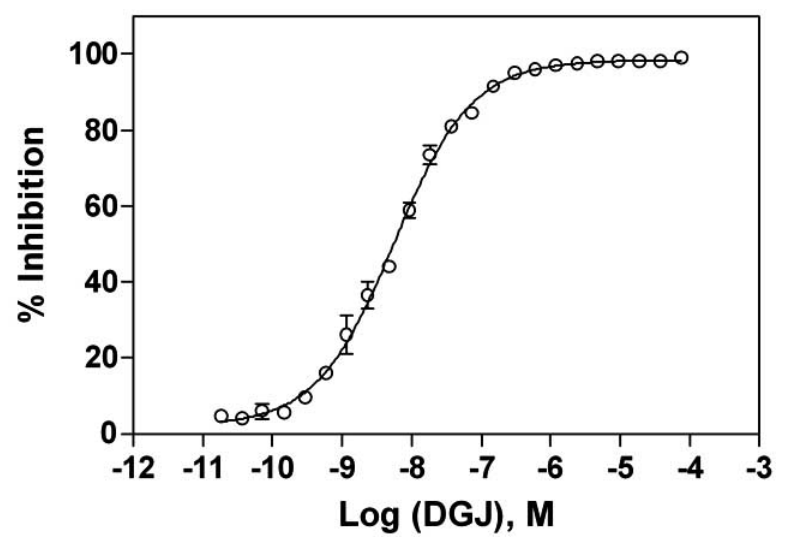

Fig. (3). Concentration response of the known GLA inhibitor, DGJ. The substrate concentration was $40 \mu \mathrm{M}$ and the enzyme concentration was $1 \mathrm{nM}$. The $\mathrm{IC}_{50}$ was found to be $5.6 \mathrm{nM}$.

\section{Screen Validation}

In order to test the performance of this enzyme assay for compound screening, we used several small collections of known bioactive compounds, including the LOPAC, Prestwick, Spectrum, and the Tocris-Timtec libraries. In a DMSO plate test without compounds, the signal-to-basal ratio from the control plate was 32.6 fold, and the $\mathrm{CV}$ and $\mathrm{Z}$ ' factor were $8.1 \%$ and 0.76 , respectively (Fig. 4). These results indicated that this GLA enzyme assay in the 1536-well plate format was robust and suitable for HTS. The qHTS results using the bioactive 6,160 compound set revealed 31 initial "hits", with a hit rate of approximately $0.50 \%$. This is in the range of the commonly desired 0.1 to $1 \%$ hit rate for HTS. However, most of these hits were weak, and were not pursued (Pubchem assay ID: 998). Three of these compounds showed relatively high inhibitory activity against GLA, and were chosen for follow-up experiments. These compounds were lansoprazole, merbromin, and phenylmercuric acetate.

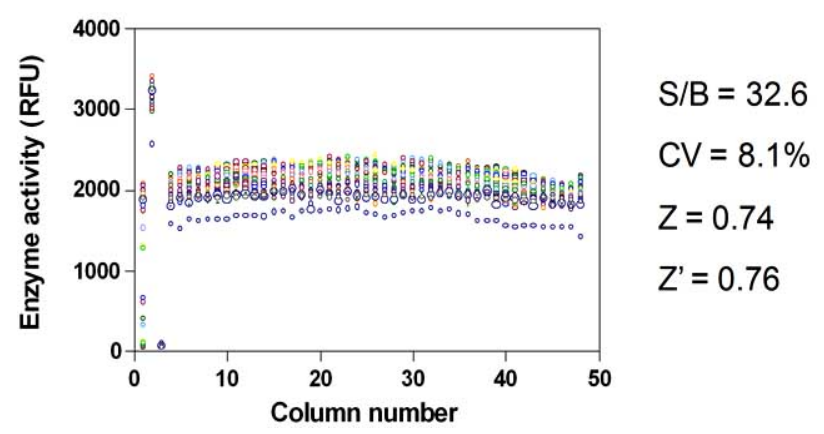

Fig. (4). Scatter plot of the results from the control DMSO plate screen. The signal-to-basal ratio was 32.6 with a $\mathrm{CV}$ of $8.1 \%$, and the $Z^{\prime}$ factor was 0.76 .

\section{Hit Confirmation and Compound Characterization}

Fresh samples of the three hits from the primary screen were obtained, and their inhibitory activities against GLA were confirmed in the same enzyme assay. To characterize the selectivity of these compounds, they were tested using other lysosomal enzyme assays. Rice $\alpha$-glucosidase (GAA) and human recombinant glucocerebrosidase (GC) were tested in similar fluorogenic enzyme assay formats. While all three compounds had little effect on GAA, they exhibited inhibitory effects against GC, as well as GLA. Among the three compounds, only lansoprazole showed selectivity for GLA over GC (Fig. 5), as its $\mathrm{IC}_{50}$ for GLA was about 19 times more potent than that for $\mathrm{GC}\left(\mathrm{IC}_{50}\right.$ for $\mathrm{GLA}$ was 6.4 $\mu \mathrm{M}$ and $\mathrm{IC}_{50}$ for $\mathrm{GC}$ was $122 \mu \mathrm{M}$ ). The other two compounds were not selective for GLA, as the activity of mer- 

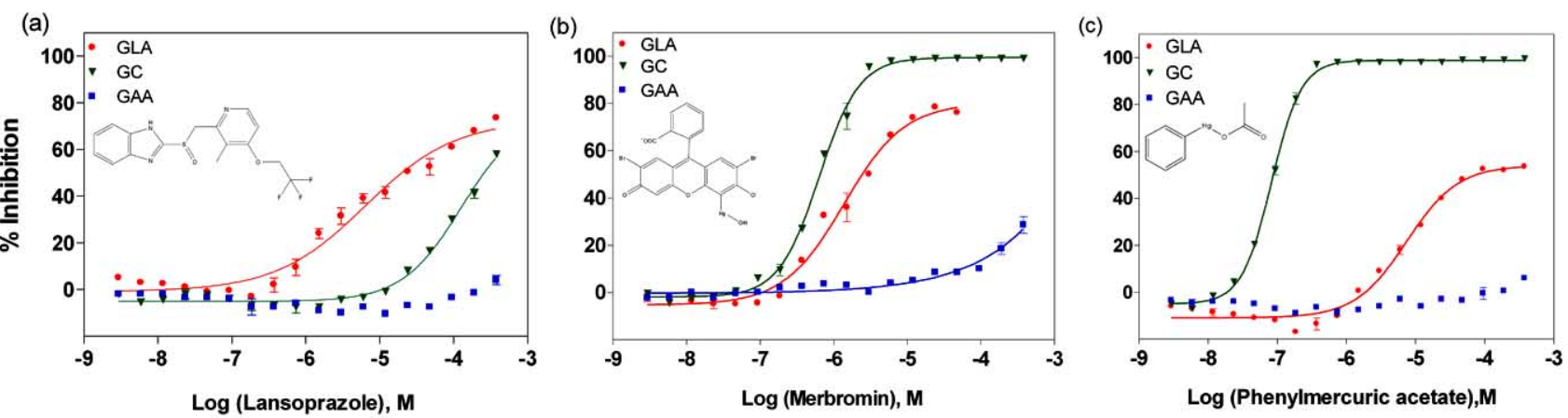

Fig. (5). Inhibition curves of the three compounds that were able to inhibit GLA. Inhibition curves for $\alpha$-glucosidase and glucocerebrosidase are also shown. (a) Lansoprazole's potency $\left(\mathrm{IC}_{50}=6.4 \mu \mathrm{M}\right)$ was about 19 times greater against GLA than GC. It did not inhibit GAA. (b) Merbromin was more potent against GC than GLA. It slightly inhibited GAA. (c) Phenylmercuric acetate was significantly more potent against GC than GLA. It did not inhibit GAA.

bromin was $0.63 \mu \mathrm{M}$ in the GC assay vs. $1.38 \mu \mathrm{M}$ in the GLA assay, and the $\mathrm{IC}_{50}$ of phenylmercuric acetate was $0.082 \mu \mathrm{M}$ in the GC assay vs. $7.42 \mu \mathrm{M}$ in the GLA assay (Fig. 5).

To characterize the mechanism of inhibition on GLA, varying concentrations of lansoprazole were tested in the GLA kinetics assay. A Lineweaver-burk plot of the results showed that the linear regression curves of the reciprocal data neither converged on the y-axis (competitive inhibition) or the $\mathrm{x}$-axis (non-competitive inhibition) (Fig. 6). The cross point of these linear regression curves was in between the $y-$ axis and $\mathrm{x}$-axis, indicating a mixed type of inhibition. Both the $K_{m}$ and $V_{\max }$ of GLA were affected in the presence of varying concentrations of this inhibitor. The $\mathrm{K}_{\mathrm{i}}$ of lansoprazole was calculated as $5.5 \mu \mathrm{M}$.

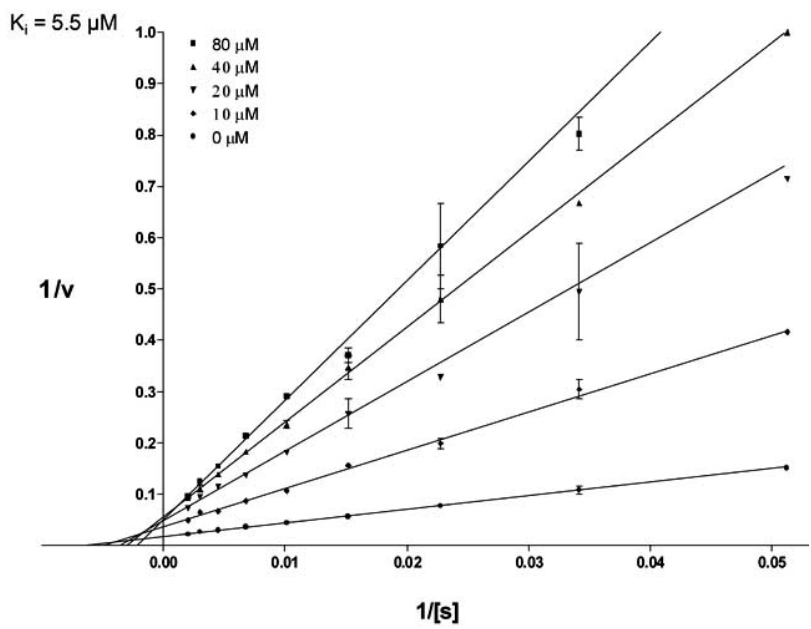

Fig. (6). Lineweaver-burk plot of the kinetic data, where various $\mathrm{K}_{\mathrm{m}}$ and $\mathrm{V}_{\max }$ values were obtained in the presence of different concentrations of inhibitor. The compound showed mixed inhibition and the inhibition constant $\left(\mathrm{K}_{\mathrm{i}}\right)$ was $5.5 \mu \mathrm{M}$.

Lansoprazole is an FDA approved drug used to treat peptic ulcers and gastroesophageal reflux disease. It inhibits the proton-pump of gastric parietal cells, and thus decreases the amount of gastric acid secretion in the stomach. It has not previously been reported to have inhibitory activity on GLA.

\section{HTS of 230,000 Compounds Using the Human Recombi- nant GLA}

Once human recombinant GLA became available for screening, the enzyme assay was optimized once again, as described above. A screen of $\sim 230,000$ diverse compounds was carried out using human enzyme in the qHTS format. The primary screen results yielded 136 hits with a hit rate of $0.06 \%$, a rate that was quite low. All of the primary results as well as the assay conditions have been deposited into Pubchem (Assay ID: 1467). Further confirmation and counter screen tests of these primary hits revealed that there were no selective and relatively potent $\left(\mathrm{IC}_{50}<50 \mu \mathrm{M}\right)$ GLA inhibitors against the human enzyme. In an additional effort to find new GLA inhibitors for the human enzyme, we developed an assay using GLA in human spleen homogenate as the enzyme source. This assay used the native enzyme from human tissue, since the GLA enzyme should be in its native conformation and in a physiologically relevant environment with subunits and co-factors. A qHTS was carried out with this assay using the same compound library and 194 primary hits were found, with a hit rate of $0.08 \%$ (Assay ID: 2107). No relatively potent GLA inhibitor $\left(\mathrm{IC}_{50}<50 \mu \mathrm{M}\right)$ remained after the confirmation and selectivity tests. In both screens, the previously identified coffee bean GLA inhibitor, lansoprazole, was not active with the human enzyme, and no enzyme activators were found as well. These negative screening results for the human GLA preparation were in contrast to screens with other lysosomal enzymes, including human glucocerebrosidase and $\alpha$-glucosidase, where potent activators and inhibitors were identified [7, 27]. The difficulty in identifying activators and inhibitors of human GLA indicates that this enzyme might be a difficult or "undruggable" target for small molecules. It should be noted that the compound libraries had little diversity in chemotypes that mimic sugars such as DGJ.

Coffee bean GLA has 59\% homology to the recombinant human enzyme [28]. It is known that two enzymes can have similar catalytic mechanisms and active sites despite a modest similarity in primary sequence, as is the case with many other proteins, such as chymotrypsin and subtilisin [29]. Despite the functional similarity of coffee bean and human GLAs, species differences in small molecule inhibition of proteins should not be unexpected, as even closely related 
(a)
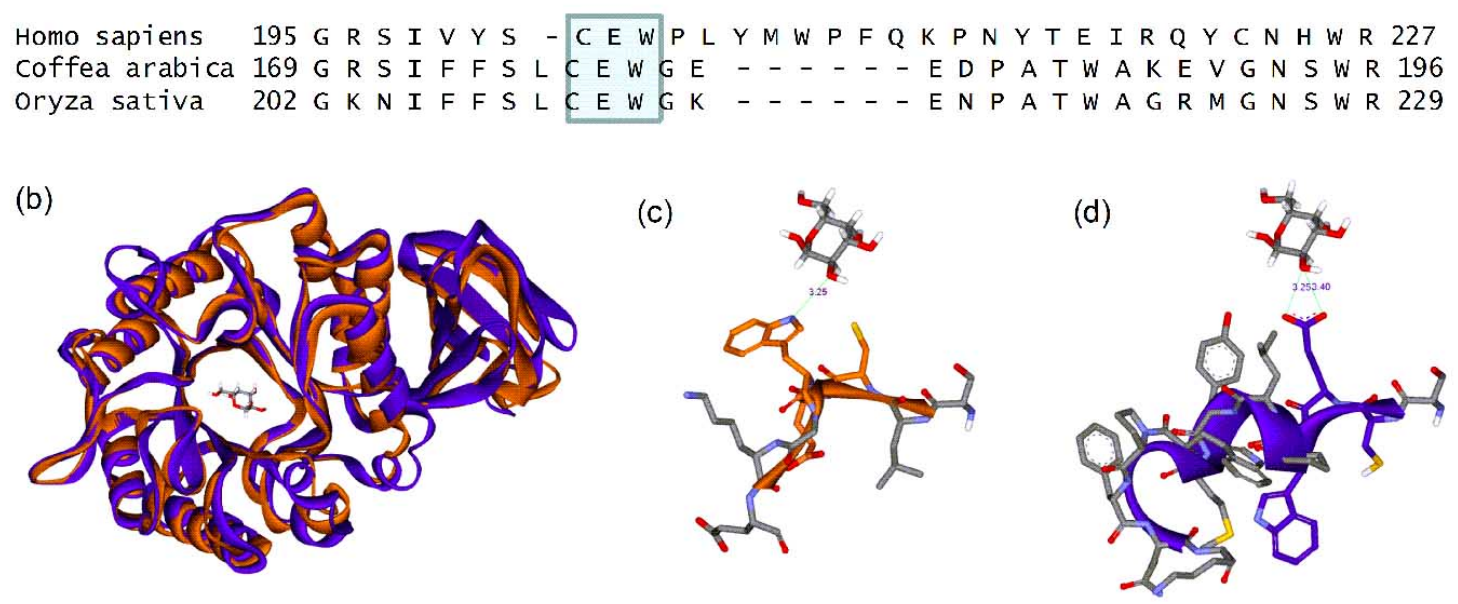

Fig. (7). Comparison of GLA structure and sequence from human, rice, and coffee bean. (a) Extract of a sequence alignment from three species, conserved residues CEW are highlighted. (b) Structural alignment of rice (orange) and human (purple) proteins. A bound galactose molecule is at the center of the figure. Protein folding is conserved between the species. (c) In the rice structure, cysteine 210 and tryptophan 212 (orange) are solvent exposed in close proximity to the bound sugar. (d) However, in the human structure, the same conserved sequence plays a very different structural role with the equivalent cysteine 202 and tryptophan 204 buried and glutamate 203 exposed, proximal to the bound sugar.

species often have important activity differences. For example, DT-diaphorase, an enzyme involved in activating antitumor compounds, responded differently to a compound depending on the source of this enzyme. It was found that human DT-diaphorase was not as effective as rat DTdiaphorase in activating cytotoxic antitumor drugs [30-32]. However, replacing one amino acid residue in the human with that present in the rat enhanced the effectiveness of the compound [30]. This indicates that a slight difference in amino acid sequence of an enzyme can cause a significant change in compound activity. Conversely, it has been observed that human TRPA1, a cation channel implicated in pain and neurogenic inflammation, is inhibited by certain trichloro(sulfanyl)ethyl benzamides, while these same compounds are inactive or serve as activators for rat TRPA1 [33, 34].

An amino acid sequence analysis shows that coffee bean GLA shares $36 \%$ identity and 59\% homlogy with human GLA [28]. There is a conserved CEW sequence in the human, coffee, and rice GLAs, as well as in other organisms (human residues 203-205), which is an important part of the active site in the human protein structure (Fig. 7 and Suppl Fig. 1). However, the crystal structure of rice GLA (PDB code: 1UAS) reveals that this conserved sequence does not support the same structural role as it does in the human protein structure (PDB code: 1R47). Tryptophan 205 is buried in the human protein structure, but its equivalent amino acid in the rice sequence is exposed to solvent. Using the rice template as a model for the coffee bean's protein structure, it might be hypothesized that this tryptophan provides support (a hot-spot) for lansoprazole binding, while its absence in the human protein active site explains why the observed activity profiles are so different between the two proteins [35]. Comparing these two proteins should give better insight into what makes one enzyme "druggable" and another not, and it may be that the difference in hydrophobic surface area provided by the coffee bean's solvent-exposed tryptophan provides the crucial difference.

\section{ACKNOWLEDGEMENTS}

This research was supported by the Molecular Libraries Initiative of the NIH Roadmap for Medical Research and the Intramural Research Programs of the National Human Genome Research Institute National Institutes of Health.

\section{SUPPLEMENTARY MATERIAL}

Supplementary material is available on the publisher's website along with the published article.

\section{REFERENCES}

[1] Desnick RJ, Ioannou YA, Eng CM. Alpha-galactosidase a deficiency: Fabry disease. $8^{\text {th }}$ ed. New York: McGraw-Hill Professional 2001.

[2] Brady RO. Enzyme replacement for lysosomal diseases. Annu Rev Med 2006; 57: 283-96.

[3] Lidove O, Joly D, Barbey F, et al. Clinical results of enzyme replacement therapy in Fabry disease: a comprehensive review of literature. Int J Clin Pract 2007; 61: 293-302.

[4] Sawkar AR, Cheng WC, Beutler E, Wong CH, Balch WE, Kelly JW. Chemical chaperones increase the cellular activity of N370S beta -glucosidase: a therapeutic strategy for Gaucher disease. Proc Natl Acad Sci USA 2002; 99: 15428-33.

[5] Sawkar AR, Adamski-Werner SL, Cheng WC, et al. Gaucher disease-associated glucocerebrosidases show mutation-dependent chemical chaperoning profiles. Chem Biol 2005; 12: 1235-44.

[6] Alfonso P, Pampin S, Estrada J, et al. Miglustat (NB-DNJ) works as a chaperone for mutated acid beta-glucosidase in cells transfected with several Gaucher disease mutations. Blood Cells Mol Dis 2005 ; 35 : 268-76.

[7] Zheng W, Padia J, Urban DJ, et al. Three classes of glucocerebrosidase inhibitors identified by quantitative high-throughput screening are chaperone leads for Gaucher disease. Proc Natl Acad Sci USA 2007; 104: 13192-7.

[8] Okumiya T, Kroos MA, Vliet LV, Takeuchi H, Van der Ploeg AT, Reuser AJ. Chemical chaperones improve transport and enhance stability of mutant alpha-glucosidases in glycogen storage disease type II. Mol Genet Metab 2007; 90: 49-57. 
[9] Parenti G, Zuppaldi A, Gabriela PM, et al. Pharmacological enhancement of mutated alpha-glucosidase activity in fibroblasts from patients with Pompe disease. Mol Ther 2007; 15: 508-14.

[10] Tropak MB, Reid SP, Guiral M, Withers SG, Mahuran D. Pharmacological enhancement of beta-hexosaminidase activity in fibroblasts from adult Tay-Sachs and Sandhoff Patients. J Biol Chem 2004; 279: 13478-87.

[11] Matsuda J, Suzuki O, Oshima A, et al. Chemical chaperone therapy for brain pathology in G(M1)-gangliosidosis. Proc Natl Acad Sci USA 2003; 100: 15912-7.

[12] Fan JQ, Ishii S. Active-site-specific chaperone therapy for Fabry disease. Yin and Yang of enzyme inhibitors. FEBS J 2007; 274: 4962-71.

[13] de Groot PG, Hamers MN, Westerveld A, Schram AW, Meera KP, Tager JM. A new immunochemical method for the quantitative measurement of specific gene products in man-rodent somatic cell hybrids. Hum Genet 1978; 44: 295-304.

[14] Yagi F, Eckhardt AE, Goldstein IJ. Glycosidases of Ehrlich ascites tumor cells and ascitic fluid--purification and substrate specificity of alpha-N-acetylgalactosaminidase and alpha-galactosidase: comparison with coffee bean alpha-galactosidase. Arch Biochem Biophys 1990; 280: 61-7.

[15] Tsou KC, Su HC. A study of yeast alpha-galactosidase with naphthyl alpha-D-galactopyranosides as chromogenic substrates. Anal Biochem 1964; 8: 415-23.

[16] Mapes CA, Sweeley CC. Galactosyl (alpha 1-4)galactosylceramide: galactosyl hydrolase activity in normal and Fabry plasma. Biochem Biophys Res Commun 1973; 53: 1317-24.

[17] Hultberg B, Sjoblad S, Ockerman PA. Glycosidases in human skin fibroblast cultures. Alpha-fucosidase, alpha-galactosidase, alphaglucosidase, beta-mannosidase, and N-acetyl-alphaglucosaminidase. Acta Paediatr Scand 1975; 64: 123-31.

[18] Shi ZD, Motabar O, Goldin E, et al. Synthesis and characterization of a new fluorogenic substrate for alpha-galactosidase. Anal Bioanal Chem 2009; 394: 1903-9.

[19] Motabar O, Shi ZD, Goldin E, et al. A new resorufin-based alphaglucosidase assay for high-throughput screening. Anal Biochem 2009; 390: 79-84.

[20] Southall N, Jadhav A, Huang R, Nguyen T, Wang Y. Enabling the large scale analysis of quantitative high throughput screening data. In: Seethala R, Zhang L, Eds. $2^{\text {nd }}$ ed. Handbook of drug screening, USA: Taylor and Francis 2009; pp. 442-62.

[21] Wang, Y, Jadhav A, Southall N, Huang R, Nguyen DT. A grid algorithm for high throughput fitting of dose-response curve data. Curr Chem Genom 2010; 4: 57-66.
[22] Shin SH, Murray GJ, Kluepfel-Stahl S, et al. Screening for pharmacological chaperones in Fabry disease. Biochem Biophys Res Commun 2007; 359: 168-73.

[23] Wenger DA, Clark C, Sattler M, Wharton C. Synthetic substrate beta-glucosidase activity in leukocytes: a reproducible method for the identification of patients and carriers of Gaucher's disease. Clin Genet 1978; 13: 145-53.

[24] Maranville E, Zhu A. The carboxyl terminus of coffee bean alphagalactosidase is critical for enzyme activity. Arch Biochem Biophys 2000; 373: 225-30.

[25] Maranville E, Zhu A. Assessment of amino-acid substitutions at tryptophan 16 in alpha-galactosidase. Eur J Biochem 2000; 267: 1495-501.

[26] Asano N, Ishii S, Kizu H, et al. In vitro inhibition and intracellular enhancement of lysosomal alpha-galactosidase A activity in Fabry lymphoblasts by 1 -deoxygalactonojirimycin and its derivatives. Eur J Biochem 2000; 267: 4179-86.

[27] Marugan JJ, Zheng W, Motabar O, et al. Evaluation of 2-thioxo2,3,5,6,7,8-hexahydropyrimido[4,5-d]pyrimidin- $4(1 \mathrm{H})$-one analogues as GAA activators. Eur J Med Chem 2010; 45: 1880-97.

[28] Zhu A, Goldstein J. Cloning and functional expression of a cDNA encoding coffee bean alpha-galactosidase. Gene 1994; 140: 227-31

[29] Kraut J. Serine proteases: structure and mechanism of catalysis. Annu Rev Biochem 1977; 46: 331-58.

[30] Chen S, Knox R, Wu K, et al. Molecular basis of the catalytic differences among DT-diaphorase of human, rat, and mouse. J Biol Chem 1997; 272: 1437-9.

[31] Walton MI, Smith PJ, Workman P. The role of NAD(P)H: quinone reductase (EC 1.6.99.2, DT-diaphorase) in the reductive bioactivation of the novel indoloquinone antitumor agent EO9. Cancer Commun 1991; 3: 199-206.

[32] Beall HD, Mulcahy RT, Siegel D, Traver RD, Gibson NW, Ross D. Metabolism of bioreductive antitumor compounds by purified rat and human DT-diaphorases. Cancer Res 1994; 54: 3196-201.

[33] Chen J, Zhang XF, Kort ME, et al. Molecular determinants of species-specific activation or blockade of TRPA1 channels. J Neurosci 2008; 28: 5063-71.

[34] Klionsky L, Tamir R, Gao B, et al. Species-specific pharmacology of Trichloro(sulfanyl)ethyl benzamides as transient receptor potential ankyrin 1 (TRPA1) antagonists. Mol Pain 2007; 3: 39.

[35] NCBI Accession numbers: GI 115482692 (rice), GI 4504009 (human) and GI 504489 (coffee bean).

Received: August 03, 2010

Revised: September 09, 2010

Accepted: October 13, 2010

(C) Motabar et al.; Licensee Bentham Open.

This is an open access article licensed under the terms of the Creative Commons Attribution Non-Commercial License (http://creativecommons.org/licenses/by-nc/3.0/) which permits unrestricted, non-commercial use, distribution and reproduction in any medium, provided the work is properly cited. 